\title{
Industrial Relation: A Comparative Study in Nigeria and Indonesia, Historical Perspective
}

Nunung Nurwati

Universitas Padjadjaran

\author{
Raden Marsha Aulia Hakim
}

Universitas Padjadjaran

\section{Mohammad Benny Alexandri}

Universitas Padjadjaran

Erna Maulina

Universitas Padjadjaran

Doi: 10.2478/mjss-2018-0092

\begin{abstract}
Indonesia and Nigeria are two countries with different histories. Both are countries once colonized by various colonial countries. The evolution of labor relations between Indonesia and Nigeria is interesting. From the perspective of history that originated from the invaders who entered what happens to both countries is one of the main attractions to examine the similarities and differences in the evolution of labor relations that occur from two different occupiers. This study examines the evolution of employment relation in developing countries, especially in Nigeria and Indonesia. This event occurred in Nigeria and Indonesia that began with the colonialist entry in both countries. This case study achieves through indepth descriptive and historical case study of the transfer of the British Voluntarist ERP to Nigeria and the history of Indonesian nationalism labor. A review of the literature of such transfer of management practices reveals that there are so much different in both perspectives of change. In an attempt to make this study can explain better about the difference, this study relies on descriptive and historical sources on the transfer of employment relation practice. The finding confirms that both countries have so many differences from many aspects.
\end{abstract}

Keywords: Nigeria, employment relationship, British Voluntarism, Indonesia Nationalism Labor, Labor Movement

\section{Introduction}

In the $18^{\text {th }}$ century, Indonesia was colonized by the Dutch. There were various developments such as economic, political, social and cultural. One of the most developed is about labor relations in Indonesia. Before Dutch came to Indonesia, many people only worked as labor. Indonesia is known as an agricultural country where there are a lot of spices and agricultural or plantation products in plentiful numbers. Natural resources in Indonesia were the reason for the Dutch to colonize Indonesia. This employment relationship began since that time.

Not much different with Indonesia, before being entered by colonial nations, Nigeria was a 
country with its agriculture economy. Ubeku (1984) says that "there was in existence employeremployee relationship in Nigeria prior to the colonial era in light of the overwhelmingly agricultural economy, culture, and traditions which were the basis for the systems of work and reward". Yesufu (1967) says, "In most cases, the employer was the family head while the employees were members of his immediate family and the extended family". For Nigeria, the employment relationship is derived from their family ties then heads of family who will be the head of labor in working groups. Besides, payment of wage to workers has not been known by the people of Nigeria. George et al. (2012) finds,

On such occasions, remuneration was mainly through the exchange of food and drinks as the economy was rural with no acceptable monetary currency or probably to reciprocate good gestures by working on another person's farm when required, or at the extreme end by providing security in terms of invasion of the friend's farm or household by an enemy and in some cases as part of the dowry for a very beautiful fiancée.

Lovejoy (1974) says that "in some cases, commodities were exchanged for goods and services; this was referred to "barter trade'". It can be reasoned that Nigeria still does not know its currency so that all exchanges will be utilizing the commodity possessed by Nigerians to get some goods or services.

Iwuji (1968) will explain the labor relations in Nigeria before the colonial nation entered,

The employer/family head was at his discretion all-in-all as he determined the reward system, recruitments, selections, promotions, and not necessarily based on merit or seniority; Provided food, housing and security for all the employees (mostly family members) and even determined when they would get married and to whom.

Ubeku (1984) says, "This system of employment relations practice was referred to the Paternalistic ERP". British Voluntarism ERP then replaced the employment relationship. It began when the Industrial Revolution in England in the $18^{\text {th }}$ and early $19^{\text {th }}$ century. British Voluntarism ERP's entry did not immediately change the employment relationship between employers and employees directly. There were cultural differences between both of them. Akporherhe (2002) says that "culture has been variously defined as the way of life of a group of people".

Evolution of the employment relationship between these two countries is fascinating from the perspective of history that started from the entry of colonial nations. What happened to these two countries at that time when the colonial nations entered Nigeria, and Indonesia becomes one of the concerns to be studied regarding see the similarities or differences of the evolution of labor relations that occur from two different colonial nations.

\section{Literature Review}

\subsection{Employment Relation}

Rose's (2004) study finds the following:

Defining employment relations involves a range of complex patterns of interactions between different Work- related groups such as trade unions and employers at the organizational level, and the state and its agencies in the region as well as the national levels.

Clegg (1972) states that "the discipline of employment relations as the study of the rules that govern employment, as well as how the rules are changed, interpreted and administered". However, the employment relationship will involve every worker in labor union and the employees which are in the highest level of organization. The labor relationship will help workers in communicating with their supervisor about any aspect related to work stuff.

Blyton and Turnbull (1998) and Kelly (1998) say "employment relations perceive as the framework within roommates complicated interactions between employees and employers are conducted, both collectively and individually". However, Blyton and Turnbull (2004) find that 
Understanding employment relations involves locating it within the broader nature of the economic activity Also Involved and taking into consideration the structural basis of the probable conflict and accommodation between employee and employer; the persuasion, as well as the manipulation of the larger society on employment relations, IS ALSO important.

Employment relations are also a part of industrial relations. As Adebisi (2013) says that "the definitional conceptualization and scope of industrial relations is a subject of much controversy due mainly to the ideological or intellectual persuasions of reviews those trying to define or conceptualize it".

In particular, communication and relation managed will refer to the creation of a common relationship which will give benefit for workers and their supervisors. Labor relations does not only try to connect workers individually but also how labor groups can feel these interrelationships. Blyton and Turnbull (2004) find the following:

Employment relations are therefore not only involved in the deployment or utilization of human resources but also in the experience as well as the expectations of labor in the workplace along with the wider society. It involves the formations and implementation of policies which included activities that are intended at enhancing the working lives of the employees; which include the strategies to enhance the competitiveness of the organization.

\subsection{Employment Relation in Nigeria}

\subsubsection{The History of the Emergence of British Voluntarist Employment Relations Practice}

Florence (1957) says, "The British Voluntarist employment relations practice was developed based on the prevailing social, political and economic philosophy at the period of the industrial revolution of the $18^{\text {th }}$ and early $19^{\text {th }}$ century in Britain". Flanders (1974) states that "this philosophy brought about individual freedom of contracts which included the employment contract, and also restrained the State from intervening directly in employment relations practice". Yesufu's (1928) study finds the following:

The forces of supply and demand were believed to be enough to Determine wages and working conditions at economically and socially acceptable levels without the State or any other institution intervening; the State has therefore played a very minimal role in the British employment relations system.

\section{Briggs (1953) and Clapham (1939) also find}

The rapid growth of industry in Great Britain at the end of the $18^{\text {th }}$ and the early $19^{\text {th }}$ century, as well as the relatively new modes of industrial structure, contributed to the creation of the British employment relations system; the factory system became predominant.

In the $18^{\text {th }}$ and early $19^{\text {th }}$ century, England experienced a rapid growth in the industry to form British Employment Relations System becoming dominant. Taylor (1842) in George et al. (2012) says that "the factory system brought about major changes in agriculture, manufacturing, and mining, which had a profound effect on the socioeconomic and cultural situation of the country". It supported the industrial revolution in England where each part of the nation was influenced by the system. Besides, Carlsson (1995) says, "There was a major transition from manual labor and draft animal-based economy to machine-based manufacturing; which brought about a new socioeconomic organization and systems". Bamford (1893) in George et al. (2012) also adds that "the new factory system brought about a new spirit of order and discipline".

Williamson (1998) in George et al. (2012) argues that this new system is "more efficient production as leakages were reduced, skills were better utilized, transportation expenses were reduced and co-ordination made Easier". Hutt (1926) adds that "this is not to conclude that there were no 'good' employers whose 'goodness' was based on religion, paternalism or both; they realized that 'good' industrial/employment relations were good for business". Ibid (1926) in George 
et al. (2012) finds

Unfortunately, the 'good' employers realized that the 'bad' employers in the same industries especially in the textile industry were undermining reviews their efforts and that there was little they could do other than for the government to intervene.

Flanders (1970) says, "The British Voluntarist employment relations practice is hinged on the following principles: the first is that 'a priority is accorded to collective bargaining over other methods of external job regulation"'. Ibid (1970) in George et al. (2012), adds that "the main feature is that trade unions and employers through their associations act as "joint authors of rules made to regulate employment contracts and ---- their own relations'”. Ibid (1970) in George et al. (2012) finds that

Both parties may solicit for the use of third party assistance for conciliation, mediation, and arbitration purposes to reach agreements. The second principle is that the British system of industrial relations has traditionally accorded a priority to voluntary over the compulsory procedural rules for collective bargaining'.

Flanders (1970) adds that "the third principle is that 'the parties to collective bargaining have preferred to build their relations more on their procedural (rather) than on their substantive rules". Nation's intervention in this system was very small compared to the developed country. It makes Kahn-Freund (1954) argues that in his study, he found

There was perhaps no major country in the world in the which the law has played a less significant role in the shaping of industrial relations than in Great Britain and in the which today the law and legal profession have less to do with labor relations.

\subsubsection{History of Wage Employment in Nigeria}

Park (1905) in George et al. (2012) says that "wage employment started with the advent of the British colonialists -Mungo Park and his team- on 20 July 1795 as they required the services of guides, and carriers when they stepped into the territory now known as Nigeria." Afigho (1991) finds an explanation that,

Mungo Park 'employed' two guides -Amadi and Isaac- whom he paid wages for their services, as was and still is the employment relations practice in the UK. Unfortunately, as at that time wage employment was generally not known in the areas to be later known as Nigeria, and Mungo Park was unaware of the implications of what he did; he unknowingly started the introduction of the British Voluntarists ERP.

Certainly, when wage employment was unconsciously introduced to Nigeria, the people could not accept the situation immediately.

Iwuyi (1968) says, "One major setback to wage employment was the lack of standardized or universally accepted currency as the silver coins were not introduced until 1872".

Dike (1956) finds

In 1912, the British pounds, shillings, and pence were introduced to all the former British colonies in West Africa including Nigeria through the West African Currency Board. Before the introduction of the bar, the cowry's shells and the Manilla, trading was by barter - using commodities as means of exchange for goods and services - These currencies could not be said to be universally accepted as they all had fluctuating values depending on the areas the transactions were taking place and the time of the year; was it during rainy season when not much of farming was done or during harvest when farmers were busy.

It shows that Nigeria was getting to go forward, by accepting their currency to serve as paid from their job.

Besides the gap which occurs in wage, working system in wage employment is very different 
from the employment relations in Nigeria. Iwuyi (1968) finds that

At the initial stage of wage employment, labor recruitments were done through the chief's who acted as the recruitment agents or third party; they in most cases used slaves, their children -the troublesome ones or children of less-favored wives - wage employment was then seen as degrading; as working for another man other than a biological relative was only done by slaves.

Ubeku (1984) adds that

The discipline involved in wage employment was not something the workers were used to as only the lowest category of slaves - those captured during the various inter-tribal wars -; followed by those slaves whose parents owing money and could not pay in time or could not pay at all- were disciplined at work.

Cultural differences in employment occurred get viewed differently from the culture in Nigeria. Hill (1976) and Yesufu (1967) finds that

In this new dispensation, workers had to report to work at a certain time, they could only go to eat at a certain time and could only close at a certain time; this was seen as the lowest degree of slavery.

Yesufu (1967) also adds that

The situation was made worst as they were fined for lateness and unauthorized absence from work: the fine was deducted from their meager salaries at the end of the month, the fines varied in amount, but half a day's pay was commonplace in the civil service.

What happens does become an issue when it is introduced to something new, as found by Bae et al. (1998) and Tayeb (1998),

The transfer of the British Voluntarist ERP to Nigeria would be problematic if not difficult mainly because the culture of the people in the country of origin, (UK) is different from the culture of the people in the country of destination, (Nigeria) just as the cultures of the people of the various ethnic groups merged to become one Nigeria are different.

Ukpabi (1987) in George et al. (2012) says that "wage employment took a new dimension when Royal Niger Company (RNC) was handed the absolute power to trade and administer the country". Ibid (1987) in George et al. (2012), adds, "The company became the first multinational company (MNC) to be granted powers to trade and rule the country with legislative, military and judicial powers". Flint (1960) states that "the Royal Charter of July 1886 gave the company powers to administer, make treaties, levy customs dues and trade in all territories in the basin of the (River) Niger and it is affluent". Cook (1943) find that

Wage employment was further made popular when for economic, political and strategic reasons the Royal Charter of the Royal Niger Company was revoked and the administrations of the Protectorates of the Northern and Southern Nigeria was taken away from a multinational company -Royal Niger Company- towards the end of 1899 and was vested directly in the hands of the British Government with effect from 1 January 1900.

It supports a lot of construction funded by England. The construction work is like lane trains or telegraph channel. Besides, wage employment also occurs in mining that requires 25,000 to 30,000 people. What happens is consistent with expectation based on Ferner and Quintanilla (1998) which states that "multinational enterprises (MNE) in most cases adopt the management practices prevalent in the parent companies". This explanation refers to how Royal Niger Company can bring British Voluntarist ERP to Nigeria.

After that, the British colonial government introduced a tax on adult male population. Yesufu (1967) finds that

The introduction of taxes for the adult male of the population forced more people to join wage 
employment, while the British Colonial Government also introduced incentives such as free medical facilities coupled with living in clean environments; these attracted more people into wage employment.

Also, there are other aspects of the lifestyle that affect wage employment. Ibid (1982) in George et al. (2012) finds the following:

The tastes of the wage earners also changed with the exposure to life in urban areas and with the contacts with the Europeans; the only way to satisfy these new tastes was to pick up a permanent wage employment, which also became a status symbol.

Dissolution of Royal Niger Company in 1899 encouraged the British Government to take over Lagos. This provided an advantage for the UK as a source of raw materials for factories in England. When World War 2 ended, 120,000 soldiers were prepared to have the capacity to work administratively as telephonist, tailors, and storekeepers. It built on insights for Nigerian regarding wage and became impacted upon foreigners who discovered cocoa or palm did not provide enough payment. Luggard (1909) in George et al. (2012) says that "the outrageous rates of pay which were instituted for the local labor of all kinds became one of the two most serious problems facing the administration".

Luggard (1909) in George et al. (2012) adds

\begin{abstract}
That the rates for the so-called skilled labor, - clerks, artisans, engineers, and pilots - were 50 percent higher than they should have been; the Indians who were considered to be more efficient earned less than their Nigerian counterparts. On the expenditures on carriers and unskilled labor, the Governor General in frustration concluded that: 'I hope largely to reduce (labor costs) by the introduction of wheeled traffic and motor cars'. He was very optimistic that with the introduction of motor cars the government wage expenditure would be drastically reduced.
\end{abstract}

However, what has been planned was not running smoothly due to many foreigners who came back to gardening than doing a government job. Luggard (1915) in George et al. (2012) says that "this made the Governor General conclude some years later that there was a notable exodus from the towns where the wage employment was in abundance into rural districts to be engaged in farming". The troubleshooting was done by recruiting the area that firstly has been colonized like Sierra Leone and Ghana. But it led to new problems, such as transport and language. Over time, the other alternative was to do forced labor by chiefs. Luggard, in this case, justified the practice, saying "among primitive tribes, a measure of compulsion through their tribal Chiefs to obtain labor construction and other famous works is justifiable as an educative process to remove fear and suspicion".

Yesufu (1967) found the following:

By 1918 the problem of labor shortage was over as there was a surplus of labor and the law of supply and demand forced down the price of labor - wages- so that even African landowners could now hire some natives.

Iwuji (1968) adds that "there was, therefore, no more need for the use of forced labor; it was then time for the government to discourage the practice until the start of the economic depression of 1930". In 1930, the International Labour Organization (ILO) had done Forced Labour Convention that declared that forced labor was illegal. Ahmed (2014) says, "The International Labour Organisation (ILO)'s conventions and recommendations are the most important international sources of Labour Law in countries across the globe including Nigeria".

At this stage, the wage employment has been accepted in Nigeria, where Nigerian Paternalistic ERP changed into British Voluntarist ERP. According to Owolabi et al. (2012), "The British Voluntarists employment relations system has come to stay in Nigeria, yet the Nigerian Paternalistic employment relations system is refusing to die". This was evident from the number of tribes in Nigeria that was still suspicious about this working relationship, so the government needed to conduct continuous education about British Voluntarist ERP. In the study done by Odesola (2009) in George et al. (2012), it can be seen that some parts of Nigeria still do education, "The 
Federal Government of Nigeria spends more money on education in the Northern States than the Southern States up till today".

\subsubsection{History Evolution of Employment Relations in Indonesia}

D.N. Aidit (1952) provides an explanation of the evolutionary development of labor relations in Indonesia. Before 1870, the exploitation run by the Dutch government to the people of Indonesia was based on the "cultuurstelsel" rules. This regulation was established in 1830 under the authority of the Governor-General Van Den Bosch (governor-general in Indonesia in 1830-1833. The "Cultuurstelsel" obligated farmers to (1) submit their land production to the Dutch government; (2) do forced labor (slavery) for the government, and (3) pay various kinds of tax. The "Cultuurstelsel" made the Dutch government held the monopoly on all export production in Indonesia.

It then led Netherland to study soil science, earth science, plant science, animal science, and so on. Imperialists used knowledge about nature and the people of Indonesia for the benefit of mining, agriculture and farming, government, and so forth. Thus, the science was used by the imperialists to deplete natural resources of Indonesia and to continue to enslave Indonesian people. Then, it realized a 'new' system in exploiting workers. In 1880, the Indonesian people were tied in contract based 'labor ordinance' and if they work less hard, they will have got a whip with a cane. They were bound by the so-called "oenale sanctie". It is the penalty provisions from the Dutch government for those, in the contract, who refuse to work or who flee because they cannot resist for torture.

Young women were also transported to plantation areas, far from their birthplace, to wage a few cents a day, and they eventually were forced to run a lot of prostitution. It made Indonesian people protested. Many nationalist movements had been done for forced labor to be stopped. Since 1895, there were three principal contradictions in imperialism in Indonesia. Three principal contradiction were:

1. the contradiction between labor and capital, between great masses of worker and smaller groups which were very rich, and because of the wealth they were in power;

2 . the contradiction between financially various groups and different groups of imperialist countries in their struggle to obtain raw material sources, to obtain foreign regions; and

3. the contradiction between a handful of ruling nations, the "cultured" with hundreds of millions of the colonial and semi-colonial nations.

The digressions made Indonesia respond. Starting in 1905, Indonesia began a labor movement. Then intellectual nobles organized themselves in 1908, and the trade groups were in 1911. Then in 1912, they expanded into a mass organization with the name of Islamic States. Indonesian labor movement was initiated by civil servants and employees of government companies. In general, those who became members of labor unions mentioned above were lowly workers because, at that time, very few people might say Indonesia occupied a prominent place in the department. If anyone is occupying an important place, so he breaks away from his people and in his social life, he categorizes himself to the European (western).

Among the unions were built by the natives, it is worth mentioning Perkoempoelan Boemipoetera Customs (1911), Persatoean Goeroe Bantoe (1912), and Personeel Fabriek Bond (1917). PFB was a union formed by Soerjopranoto which would later be known as one of the "kings of strikes" for the Dutch. The strikes that PFB made focused on three objectives, namely: (1) trying to get the power in the government so that the country is run by the people themselves and they can take care of fortune, (2) tightening the workers to take their destiny in their work, and (3) making trading by and for the people (cooperatives)".

During the reign of President Soekarno in 1950, Soekarno decided to invite the progressive elements in the formation of his cabinet, SOBSI had it back up and gained strength in the decade. In the decade, SOBSI was the largest and most powerful trade union in Indonesia within its 2.5 million members and thirty-four trade unions members. Besides SOBSI, two more progressive trade unions were worth to mention. The first is GASBRI (Association of Revolutionary Labors Union of Indonesia) that was closely related to Murba Party. Murba Party itself is a developing result of a group of people who broke away from SOBSI in 1946. A congress in 1951, GASBRI changed its 
name into SOBRI (Central Organization of Revolutionary Labors of Indonesia). The second is SARBUPRI (The Plantation Labor Union of the Republic of Indonesia) that was established in 1947. SARBUPRI had a closeness to SOBSI and other mass organizations that were also close to the Communist Party of Indonesia.

All three labor unions have often held a major strike which ended in victory for the labors. Statistic facts show that between the years 1921-1955, it occurred 11,763 strikes involving 918,739 workers. The actions of nationalization done by unions have resulted in major victories everywhere. Although later, the unions did not enjoy the victories very much even many Dutch companies which have successfully been nationalized and then taken over by the Army. Demands to be involved in the production process also had been won. President Soekarno supported this program and ordered to form the Board of Company in 1960, where workers domiciled in the Advisory Council.

New Order Government was determined to implement Pancasila in pure and consistent manner, and it was also committed to developing well-planned sustainable and continuous programs. In order unification and simplification of worker' organizations, on the $1^{\text {st }}$ November 1969, MPBI was formed. In May 1972, as a follow-up from the previous seminar, MPBI held a plenary meeting to discuss in depth about the renewal and simplification of the existence of SPSI. Of the trial, it was formed "joint pledge" in which the point was as follows: reforming the structure of labor movement so that the union continues to function economically and socially and to be oriented to development. From this MPBI pledge on $20^{\text {th }}$ February 1973 , it was born "a declaration of the unity of the labors throughout Indonesia". There are two exceptionally historic things within the introduction of FBSI in particular: (1) the unions have succeeded together in one space that has been an obsession for every union leader and (2) the unions have managed to escape from political activities and become professional and independent unions.

\section{Methodology}

This study examines the evolution of employment relation in developing countries, especially in Nigeria and Indonesia. This event took place in Nigeria and Indonesia that began with the colonialist entry in both countries.

This case study achieves through in-depth descriptive and historical case study of the transfer of the British Voluntarist ERP to Nigeria and the history of Indonesian nationalism labor. A review of the literature of such transfer of management practices reveals that there are so much different in both perspectives of change.

\section{Discussion}

If this study is viewed from the historical development of employment relations that occur in both developing countries, namely, Nigeria and Indonesia. Colonial nations influence both. Nigeria is one of the countries colonized by the British colonial nation, and it successfully became independent in 1960. The presence of a colony from colonial nations has brought Nigeria to know more about the working relationship between workers and supervisors. This is evident from their wages. The following figure shows the process that occurs at the transition change from paternalistic Nigeria to become British Voluntarist ERP:

$$
\text { Paternalistic Nigeria ERP }
$$
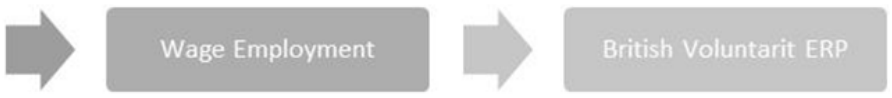

Figure 1: The Nigerian Change Scheme

Besides, Indonesia is also one of the countries colonized by the Dutch colonial and it got its independence in 1945. Indonesia also experienced changes in labor relations, starting from Indonesia labor colonized because of the "culture system" until there is the labor movement in raising the better level of Indonesian workers. It can be seen from the description how the process changes: 


\section{cultuurstelsel}

Figure 2: Indonesia Change Scheme

Once you know how the process of change of the employment relationship that occurs in the study of literature and the history of these two developing countries, they certainly have each other's differences. This can be seen in the following table:

Table 1: Similarities and Differences

\begin{tabular}{|c|l|l|l|}
\hline No. & & Nigeria & Indonesia \\
\hline 1. & Occupation & Farmer & Farmer \\
\hline 2. & Labor Relation & Paternalistic & cultuutstelsel \\
\hline 3. & $\begin{array}{l}\text { Labor Relations } \\
\text { Situation }\end{array}$ & $\begin{array}{l}\text { Working groups based on family } \\
\text { relationships }\end{array}$ & Indonesian labor must provide crops, slavery \\
\hline 4. & Labor Payment System & Goods exchange system & No payment by the invaders must pay taxes \\
\hline 5. & Transition Period & wage employment & $\begin{array}{l}\text { The 'new' system with work contracts 'rough } \\
\text { workers' }\end{array}$ \\
\hline 6. & $\begin{array}{l}\text { Labor relations in } \\
\text { transition }\end{array}$ & Labor is paid & $\begin{array}{l}\text { Labor is bound by the "poenale sanctie" } \\
\text { provisions by the Dutch government }\end{array}$ \\
\hline 7. & Labor Relation & British Voluntarist & Labor Movement \\
\hline 8. & $\begin{array}{l}\text { Carrier changes in labor } \\
\text { relations }\end{array}$ & $\begin{array}{l}\text { The existence of wages and } \\
\text { government employment }\end{array}$ & The existence of strikes \\
\hline 10. & $\begin{array}{l}\text { Beginning of new labor } \\
\text { relations }\end{array}$ & Industrial revolution in England & $\begin{array}{l}\text { The Foreign Workers who made the labor } \\
\text { movement for the first time }\end{array}$ \\
\hline 11. & $\begin{array}{l}\text { The purpose of the new } \\
\text { labor relations }\end{array}$ & $\begin{array}{l}\text { Individual freedom in the } \\
\text { employment contract }\end{array}$ & $\begin{array}{l}\text { Workers of political activity and become } \\
\text { professional and independent }\end{array}$ \\
\hline 12. & Constraints of change & Culture & Country Independence \\
\hline 13. & Successful Changes & Welfare & Nationalism and Independence \\
\hline
\end{tabular}

Source: processed by researchers (2017)

In Table 1, it can be seen the differences or similarities that occur from changes in labor relations in both developing countries. The two countries have their mission which finally is successful to make differences of their country. It is not easy, and it takes time for many years.

\section{Conclusion}

In this research, the changes that occur in Nigeria have led to some problems because of cultural differences between Nigeria and British. Many ethnic groups are still not familiar with the labor relations so that these changes make it difficult to continue. Additionally, for Indonesia, the change itself is a nationalist movement fighting for independence for the country. It was fundamental as a result of colonization was done by the colonial make farmers endure.

\section{Reference}

Adebisi, Moses Adesola. 2013. History and Development of Industrial Relations in Nigeria: Hybridity of Western Models versus Military Interventionism Culture. Mediterranean Journal of Social Science, Vol. 4(14), pp. 687-693.

Afigbo, A. E. 1991. Background to Nigerian Federalism: Federal Features in the Colonial State. The Journal of Federalism (21): 40-52

Ahmed, A.B. 2014. Emerging Trends in Labour Law and Industrial Relations in Nigeria. International Journal of Humanities and Social Science, Vol. 4(11), pp. 29-44.

Akporherhe, F. 2002. The Challenge of English and other foreign languages on Nigerian culture. Journal of Nigerian Languages and Culture, 3, 29-33. 
Bae, J., Chen, S., \& Lawler, J. 1998. Variation in HRM in Asian countries: MNC home country and host countries effects. International Journal of Human Resource Management, 9(4), 653-70

Blyton, P and Turnbull P. 1998, 2004. The Dynamics of Employee Relations. Basingstroke: Macmillan.

Briggs, T. 1953. Do we get our money's worth? The Educational Forum, 18(1), 5-13.

Carlsson, B. 1995. Technological Systems and Economic Performance: The Case of Factory Automation. Kluwer Academic Publishers Group.

Clapham, J. H. 1926, 1939. An Economic History of Modern Britain. Cambridge University Press.

Clegg, H.A. 1972. The system of Industrial Relations in Great Britain. Blackwell.

Cook, A. N. 1943. British Enterprises in Nigeria. Oxford University Press

Dike, K.O. 1956. Trade and Politics in the Niger Delta, 1830-1885: An Introduction to the Economic and Political History of Nigeria. Oxford Clarendon Press.

D.N. Aidit. 1952. Sedjarah Gerakan Buruh Indonesia. Jakarta: Jajasan

Ferner, A \& Quintanivilla, J. 1998. Multinational, national business systems and HRM: the enduring influence of national identity or a process of 'Anglo-Saxonization. The International Journal of Human Resource Management, 9(4), 710-731

Flanders, A. 1974. Management and Unions: The Theory and Reform of Industrial Relations. London: Faber.

Flanders, A. 1970. Management and Unions. Faber and Faber London.

Flint, J.E. 1960. Sir George Goldie and the Making of Nigeria. London: Oxford University Press.

Florence, 1957. Limits of Laissez-faire in Tomlison, J. (1994) in, Government and the Enterprise since 1900, Oxford University Press.

George, Owoyemi dan Onokala. 2012. Evolution of Employment and Industrial Relation practice: The Nigerian Experience. International Journal of Business and Social Science, Vol 13, No.12.

Hill, P. 1976. From Slavery to Freedom: The Case of Farm-Slavery in Nigeria Hausaland. Comparative Studies in Society and History, 18 (3): 393-426.

Hutt, W. H. 1926. The Factory system of the Early 19th Century. Economica, 16: 78-93.

Iwuyi, E. C. 1968. International Handbook of Industrial Relations Contemporary Developments and Research. Aldwych Press.

Kahn- Freund, O. 1954. Legal framework, In A. Flanders and H. Clegg (eds). The System of Industrial Relations in Great Britain: 42-127.

Kelly J. 1998. Rethinking Industrial Relations: Mobilization, Collectivism and Long Waves. London: Routledge.

Lovejoy, P.E. 1974. Interregional Monetary Flows in the Pre-Colonial Nigeria. Journal of African History, XV (4): 563-585.

Olusoji, J.G., Owolabi L.K., \& Uchechi C.O. 2012. Culture and Management Practices are Siamese Twins: The Case of Employment Relation Practices in Nigeria (Cadbury Nigeria Plc) and the United Kingdom (Cadbury Worldwide UK). Business and Management Review, Vol. 2(2), pp. 09-12.

Rose, Ed 2004. Employment Relations. Prentice Hall.

Tayeb, M. 1998. Transfer of HRM practices across cultures: An American Company in Scotland. International Journal of Human Resource Management, 9(2): 332-358

Ubeku, A.K. 1984. Personnel Management in Nigeria. Macmillian.

Yesufu, T.M. 1967. The State and Industrial Relations in Developing Countries. Industrial Relations and Economic Development (Published for the International Institute for Labour).

Yesufu, T.M. 1982. The Dynamics of Industrial Relations: The Nigerian Experience. University Press Limited Ibadan. 